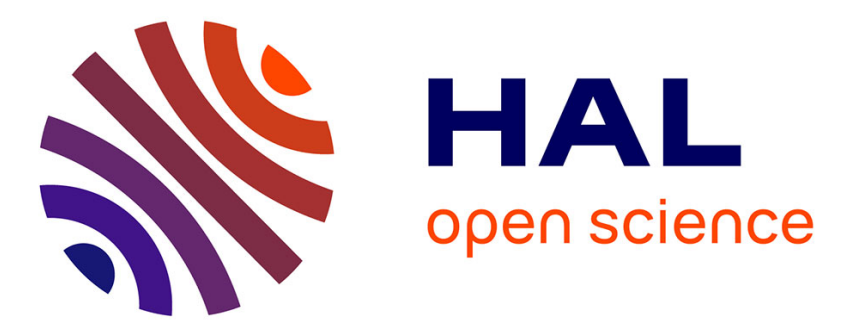

\title{
Organically bound tritium (OBT) and carbon-14 accumulation in the sediments off the mouth of the Rhône river
}

Philippe Jean-Baptiste, M. Fontugne, E. Fourré, S. Charmasson, L. Marang, F. Siclet

\section{To cite this version:}

Philippe Jean-Baptiste, M. Fontugne, E. Fourré, S. Charmasson, L. Marang, et al.. Organically bound tritium (OBT) and carbon-14 accumulation in the sediments off the mouth of the Rhone river. Environmental Earth Sciences, 2019, 78 (3), pp.78. 10.1007/s12665-019-8081-y · hal-02457944

\section{HAL Id: hal-02457944 https://hal.science/hal-02457944}

Submitted on 3 Jun 2020

HAL is a multi-disciplinary open access archive for the deposit and dissemination of scientific research documents, whether they are published or not. The documents may come from teaching and research institutions in France or abroad, or from public or private research centers.
L'archive ouverte pluridisciplinaire HAL, est destinée au dépôt et à la diffusion de documents scientifiques de niveau recherche, publiés ou non, émanant des établissements d'enseignement et de recherche français ou étrangers, des laboratoires publics ou privés. 

(6)

\section{Organically Bound Tritium (OBT) and Carbon-14 accumulation in the} sediments off the mouth of the Rhône river

P. Jean-Baptiste ${ }^{1}$, M. Fontugne ${ }^{1}$, E. Fourré ${ }^{1}$, S. Charmasson ${ }^{2}$, L. Marang ${ }^{3}$, F. Siclet ${ }^{3}$

${ }^{1}$ CEA-CNRS-UVSQ, Laboratoire des Sciences du Climat et de l'Environnement, Centre de Saclay, 91191, Gif-sur-Yvette, France

${ }^{2}$ IRSN, PSE-ENVISRTE, Laboratoire de Recherche sur les Transferts des radionucléides au sein des écosystèmes Aquatiques (LRTA), Centre IFREMER, 83507 La Seyne-sur-Mer, France.

${ }^{3} E D F-R \& D$, Laboratoire National Hydraulique et Environnement, 6 Quai Wattier, 78401 Chatou, France

Corresponding author: Philippe Jean-Baptiste (pjb@|sce.ipsl.fr) (6)

\section{Abstract}

We have studied the recent history of Organically Bound Tritium (OBT) and carbon-14 in suspended organic matter carried by the Rhône from the analysis of two cores collected in the sedimentary cone off the river mouth. Measured OBT and carbon-14 concentrations highlight characteristic anthropogenic traces in the suspended matter of the Rhône, with a peak of tritium and carbon-14 commencing at the start of the 1970's and extending over some thirty years. In spite of the influence of the atmospheric nuclear tests of the 1950's and 1960's and of the discharges of carbon-14 by the nuclear industries located along the Rhône, carbon-14 levels are 
27 low due to the diluting effect of a refractory carbon component very low in carbon-14 28 present in the coastal sediments. Organically bound tritium (OBT) levels are well 29 above the modern background created by the global imprint of bomb-tritium. Detailed 30 study of the impact of the various contribution to the tritium peak indicates that these 31 traces are mostly the result of the sediments in the Rhône being contaminated by 32 past tritium releases by the watchmaking industry in the upper Rhône.

35 Keywords: Rhône prodelta; tritium; carbon-14; radioactive contamination; 36 watchmaking industry 


\section{Introduction}

The Rhône valley and the french nuclear-based industry share a long common history that started in the 1950 s and 1960 s with the commissioning of several major nuclear facilities dedicated to the production and reprocessing of plutonium and tritium. Today, the Rhône valley has the highest density of nuclear activities in Europe (Fig. 1), comprising two major nuclear sites (Marcoule and Tricastin) housing civilian and military activities and four nuclear power plants (Bugey, Saint-Alban, Cruas, Tricastin) with a total of 14 reactors (to which Crey-Malville should be added; this reactor was decommissioned in 1997). Over this period, a repository of artificial radionuclides has built up in the sediments delivered to the Mediterranean Sea and deposited in the sedimentary prism (Rhône prodelta) off the mouth of Rhône river. These sediments enable us to reconstruct the history of the inputs to the river of some radionuclides, including ${ }^{60} \mathrm{Co},{ }^{137} \mathrm{Cs},{ }^{238} \mathrm{Pu},{ }^{239,240} \mathrm{Pu}$ (Charmasson et al., 1998; Charmasson, 2003 ; Lansard et al., 2007). This paper presents a study of the vertical distribution of organically bound tritium (OBT) and carbon-14 in two sediment cores taken from the Rhone prodelta. The aim of the study was to obtain the first historical record of these two radionuclides in the suspended matter of the Rhône and to evaluate the extent of anthropogenic tritium and carbon-14 accumulation in the Rhône prodelta. Throughout the text, tritium levels are expressed in Tritium Units (TU), 1 TU corresponding to a $\mathrm{T} / \mathrm{H}$ ratio of $10^{-18}$. The unit used for carbon-14 is the pmC (\% modern Carbon): with this unit, the pre-industrial specific activity for carbon14 (226 Bq/kgC) corresponds to 100 pmC (Mook and van der Plicht, 1999).

\section{Background}


The Rhône ( $812 \mathrm{~km}$ long) is one of the main rivers in Europe. It rises in the Swiss Alps at an altitude of 2,200 $\mathrm{m}$ and ends in the Camargue delta before flowing into the Gulf of Lyon, a large continental shelf located in the northwestern Mediterranean Sea. It is the largest river flowing into the western Mediterranean basin, both in terms of water and particulate matter, accounting for $80 \%$ of the solid riverine inputs to the Gulf of Lions (Monaco et al., 1990). At the mouth of the Rhône the particulate matter settles quickly and creates a sedimentary prism. Its proximal fan, as the extension to the Rhône's land-based channel, is marked by a slight slope. The prodelta itself starts with a clean break to the slope and extends to a depth of $60 \mathrm{~m}$. It is characterised by the highest rates of sedimentation in the Gulf of Lion, reaching up to between 0.2 and $0.5 \mathrm{~m} \mathrm{yr}^{-1}$ (Charmasson et al., 1998). The distal fan, below a depth of $60 \mathrm{~m}$, corresponds to a second break in the slope and is characterised by less energetic hydrodynamics that favour finer particles settling with sedimentation rates no greater than a few millimetres per year (Radakovitch et al., 1999). This sedimentary complex captures a large proportion of the pollutants carried by the Rhône.

\section{Origin of carbon-14 and tritium in the organic matter of Rhône sediments}

The origin of the particulate organic matter in the Rhône is $90 \%$ non-native (allochthonous), in other words due to the leaching of the catchment areas (Lansard et al., 2009 ; Hamelin-Vivien et al., 2010). The remaining $10 \%$ corresponds to the autochtonous organic matter, that is the organic matter photosynthesised by plants in the river itself. As a consequence, the carbon-14 and tritium tagging of organic suspended matter in the Rhône has two origins: the export of organic residues from 
87 catchment areas, influenced by the tritium (HTO) and carbon-14 atmospheric contents, and organic matter formed in-situ, influenced by the tritium and carbon-14 content of the Rhône waters.

\subsection{Natural sources}

Tritium $\left({ }^{3} \mathrm{H}\right)$ and carbon-14 $\left({ }^{14} \mathrm{C}\right)$ are produced naturally in the atmosphere by the effect of cosmic radiation principally on nitrogen. Tritium enters into the water cycle in the form of a molecule of tritiated water (HTO), then spreads into the biosphere as Tissus Free Water Tritium (TFWT) and organically bound tritium (OBT) - Eyrolle et al., (2018). The natural $\mathrm{T} / \mathrm{H}$ ratio for surface waters is in the range $10^{-18}-10^{-17}$, i.e. 1 to 10 TU (Cauquoin et al., 2015). In the same way, carbon-14 is oxidised to form a molecule of carbon dioxide $\left({ }^{14} \mathrm{CO}_{2}\right)$ that enters the natural cycle of organic carbon (photosynthesis) and inorganic carbon.

\subsection{Global human-made inputs}

Substantial amounts of tritium and carbon-14 were released into the environment by the atmospheric nuclear tests of the 1950's and 1960's. When the test ban treaty came into force in 1963, the atmospheric content of carbon-14 had reached 200 pmC, i.e. twice the natural level (Nydal and Lövseth, 1996) and that of tritium 2,000 TU in the northern hemisphere (IAEA water isotopes database at https://nucleus.iaea.org /wiser/gnip.php). Because carbon and hydrogen in the biosphere equilibrates isotopically with the atmosphere, this global tritium and carbon-14 imprint of the atmospheric nuclear tests is recorded in vegetation, and therefore, in the organic matter deposited in particulate form in the Rhône and along the Mediterranean coast, associated with the leaching of organic material in the soil. 
112 3.3. Tritium and carbon-14 of local industrial origin

113 3.3.1 Local gaseous discharges of carbon-14 and tritium (HTO)

114 Atmospheric discharges of tritium (HTO) influencing the Rhône catchment are

115 mainly due to the nuclear activities of the Marcoule site, operated by the French

116 Atomic Energy Commission (CEA) and the AREVA company, and of the CEA-Valduc

117 military site (Fig. 2); gaseous tritium discharges from the nuclear power stations

118 currently make up less than $1 \%$ of the total (and hence even less in the past). These

119 atmospheric discharges of tritium produce substantial local traces in the land

120 environment. The data available for the Marcoule site indicates levels of tritium (OBT)

121 in the organic matter of plants up to 20,000 TU for the most exposed zones

122 (Rousset-Debet, 2012). Measurements taken for lichens in Valduc (Daillant et al.,

123 2001) indicate maximum values on the order of 80,000 TU for the most exposed

124 lichens. Since the origin of the particulate organic matter in the Rhône is $90 \%$ non-

125 native (allochthonous), in other words due to the leaching of the catchment areas

126 (Lansard et al., 2009; Hamelin-Vivien et al., 2010), the leaching of tritiated organic

127 material in soil may therefore have a significant effect on organic tritium in suspended

128 matter and sediments.

129 With respect to airborne discharges of carbon-14, only recent data are available,

130 because previously carbon-14 releases were not recorded separately from other

131 beta/gamma emitters. Anyway, the traces in the land environment due to discharges

132 into the atmosphere of carbon-14 are low due to a net predominance (80\%) of

133 discharges in the form of methane (Le Guen and Siclet, 2009) that cannot be

134 absorbed by vegetation. Nevertheless, a slight increase is noted in the local land

135 vegetation on the order of $5 \%$ to $15 \%$ (Roussel-Debet, 2012). 
137 3.3.2 Direct liquid discharges of carbon-14 and tritium (HTO) into the Rhône

138 The two major contributors to liquid discharges of tritium (in the form of HTO) into

139 the Rhône river are the Marcoule nuclear site and the nuclear power plants (Jean-

140 Baptiste et al., 2018). In the past, Marcoule releases were predominant, but today

141 releases are mainly due to the nuclear power plants (Fig. 3). Unfortunately, as noted

142 above for carbon-14 airborne discharges, only recent data for liquid discharges of

143 carbon-14 are available, because previously carbon-14 releases were not recorded

144 separately from other beta/gamma emitters.

146 3.3.3 Indirect liquid discharges of tritium (HTO) into the Rhône

147 CEA-Valduc is located in Bourgogne to the north-east of Dijon. The local 148 hydrology connects it to the Rhône via the Tille and the Saône. Although its tritium 149 discharges are in gaseous form only (mostly HTO), when a large amount of tritium (in 150 the form of HTO) are released into the atmosphere, it produces significant local 151 traces in the river network (Guétat et al., 2013). In the absence of dedicated studies,

152 the extent of the tritium contamination of the rivers around Marcoule and Valduc are 153 not known precisely. For several decades CEA-Valduc was the largest emitter of 154 tritium in the atmosphere in France. Based on the data of Guétat et al. (2013), the 155 proportion of tritium from gaseous discharges carried away by the local river network 156 can be estimated at around $2 \%$ (Jean-Baptiste et al., 2018). Here, we assume that 157 this figure also applies to Marcoule. 
Substantial quantities of tritium (as a substitute for radium) were used between 1960 and 1990 by the watchmaking industry (Krejci and Zeller, 1979). Several

162 production units for fluorescent paints based on tritiated polystyrene supplied numerous watchmaking workshops, principally in Switzerland but also, to a lesser extent, in eastern France. This use of tritiated organic material is linked with the significant traces found in sediments and suspended matter of the Rhône (Gontier and Siclet, 2011; Jean-Baptiste et al., 2018), although we cannot say if these are due to past direct deposits into the Rhône or indirect deposits via the catchment areas. These traces are at their highest in the upper Rhône, upstream of Creys Malville, the northernmost nuclear power station on the Rhône, with current values in sediments between $10^{5}-10^{6} \mathrm{TU}$ (Jean-Baptiste et al., 2007) but are observed all along the river (Fig. 4). This situation is only found in the Rhône - no such tritium contamination of the sediments is observed for the other major French rivers where nuclear power stations are also in operation (Gontier and Siclet, 2011).

\section{Methods}

KBROUS and KB-06 cores were analysed to determine the amounts of tritium (OBT) and carbon-14 in the sedimentary organic matter. The sediment cores were taken with a Kullenberg corer in November 2001 during the REMORA 2 campaign of the French Institute of Radioprotection and Nuclear Safety (IRSN). The KBROUS core was extracted close to the mouth of the Rhône $\left(43^{\circ} 18.30^{\prime} \mathrm{N}, 4^{\circ} 51.01^{\prime} \mathrm{E}\right)$ where the sedimentation rates are the highest, thus ensuring a good temporal resolution,

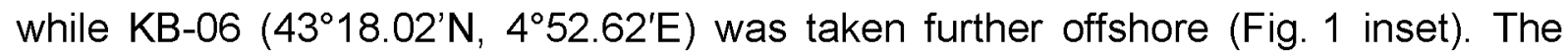
cores were kept in cold storage and then cut into $10 \mathrm{~cm}$ sections. The sediment 
samples were then lyophilised during 48 hours to ensure a complete removal of the water, passed through a $2 \mathrm{~mm}$ sieve, ground up, then packaged in sealed plastic bags.

The amount of tritium was determined by mass spectrometry using the ${ }^{3} \mathrm{He}$ regrowth method (Clarke et al., 1976), with a detection limit below $0.1 \mathrm{TU}$. The dried sediment powder (typically $150 \mathrm{~g}$ ) was transferred into a $100 \mathrm{~mL}$ low helium diffusivity Corning 1724 glass bulb. To minimise ${ }^{3} \mathrm{He}$ blank, the bulbs were previously baked in a flow of argon at $600^{\circ} \mathrm{C}$ for 24 hours to remove the helium dissolved in the glass. All manipulations were undertaken in a glove-box flushed with argon to minimize contamination by ambient air moisture. The bulbs were attached to a high vacuum line and evacuated down to $<10^{-5}$ Torr, they were then flame-sealed. After sealing, the samples were stored at $-20^{\circ} \mathrm{C}$ to further minimise helium diffusion through glass (Jean-Baptiste et al., 1989). After a period of storage of typically $100-$ 150 days, the bulbs were connected to the inlet line of a mass spectrometer for ${ }^{3} \mathrm{He}$ analysis. The instrument is a MAP 215-50 noble gas mass spectrometer equipped with a stainless steel low blank inlet system $\left({ }^{3} \mathrm{He}\right.$ blank $\left.<3 \times 10^{-20} \mathrm{~mol}\right)$. The analysis protocol is described in detail by Jean-Baptiste et al. (2010).

The carbon-14 activities were measured by Accelerator Mass Spectrometry (AMS) at the LMC14-ARTEMIS facility (Saclay). The sediment samples were decarbonated $(\mathrm{HCl} 0.5 \mathrm{~N})$ and rinsed with de-ionised water before being dried at $60^{\circ} \mathrm{C}$ in a drying oven at the Laboratoire des Sciences du Climat et de l'Environnement (LSCE). The samples were then introduced into quartz tubes in the presence of 500 $\mathrm{mg}$ of copper oxide and a silver thread. They were then heated to $835^{\circ} \mathrm{C}$ for 6 hours in order to transform the organic material into $\mathrm{CO}_{2}$ (Hatté et al., 2003). 
Accuracies on tritium and carbon-14 measurements are given in the tables of 210 results.

211 In addition, following Gauthier and Hatté (2008), a few milligrams of sediment

212 were used to measure the stable organic carbon isotope composition $\left(\delta^{13} \mathrm{C}\right)$. The 213 measurements were carried out by EA-IRMS in continuous flow coupling an 214 elementary analyser (Fisons Instrument NA 1500 Element Analyser) to a mass 215 spectrometer (Thermo-Finigan Delta + XP Isotope-Ratio Mass Spectrometer). The $216 \quad \delta^{13} \mathrm{C}$ is expressed in \%o with respect to the standard PDB (Pee Dee Belemnite), with 217 precision of $\pm 0.08 \%$.

\section{Results}

The vertical profiles of organically bound tritium (OBT) and carbon-14 are shown in Fig. 5 (see also Table 1 and 2). From the base to the top, the vertical profile of OBT in the KBROUS core displays an increase up to an initial peak at $390 \mathrm{~cm}$ depth, followed by two other peaks at 280 and $240 \mathrm{~cm}$. The upper part of the core $(230 \mathrm{~cm}$ 226 to $0 \mathrm{~cm}$ ) shows a decrease in tritium content. A peak of OBT is also present in the 227 KB-06 core, with a maximum much nearer to the surface (30-40 cm deep) due to 228 the lower sedimentation rate in this area.

The vertical profiles of carbon-14 present similar variations but the difference 230 between the peaks and the baseline is much lower than for tritium. The carbon-14 231 activities are low (the majority are lower than $100 \mathrm{pmC}$ ) due to the diluting effect of 232 an ancient refractory carbon component very low in carbon-14 ( $0 \mathrm{pmC})$ present in 
233 the coastal sediments held in suspension (Cathalot et al., 2013). Taking $100 \mathrm{pmC}$ as

234 a reference for pre-industrial carbon-14, the baseline values for KB-06 (37 pmC)

235 correspond to $37 \%-63 \%$ mixture of modern organic matter and ancient refractory

236 carbon. Using this mixing ratio, the peak value of $79.98 \mathrm{pmC}$ recorded in the $\mathrm{KB}-06$

237 core corresponds to a modern organic matter maximum of $216 \mathrm{pmC}$. This value is

238 close to the carbon-14 bomb-peak value of $200 \mathrm{pmC}$ (Nydal and Lövseth, 1996).

239 Hence it does appear that a significant contribution from the carbon-14 bomb-peak

240 may have been captured in this sedimentary record.

$241 \quad \delta^{13} \mathrm{C}$ of organic carbon is reported in Tables 1 and 2. Values range between 242 25.11\%o and $-26.70 \%$ for KB-06 and between $-25.11 \%$ and $-27.31 \%$ for KBROUS.

$243 \quad \delta^{13} \mathrm{C}$ values within KB-06 are slightly greater than those of KBROUS, consistent with

244 the location of the core where there is more influence of marine conditions (see

245 below). The two cores display, from the base to the top, a similar and regular 246 decrease in the carbon isotopic composition, in good agreement with observations 247 for recent sediments and soils (Bentaleb and Fontugne, 1996): this 1\%o-1.5\%o 248 decrease in $\delta^{13} \mathrm{C}$ values has to be related to the Suess effect and the atmospheric 249 input of $\mathrm{CO}_{2}$ with a low ${ }^{13} \mathrm{C} /{ }^{12} \mathrm{C}$ ratio resulting from the combustion of fossil fuel since 250 the beginning of the industrial period (Friedly et al., 1986; Trundiger et al., 1999).

251 The cores received organic carbon from two sources: terrestrial suspended

252 matter from the Rhône and marine phytoplankton from the Mediterranean. In most 253 sedimentary environment marine planktonic organic carbon is isotopically heavier 254 than that of the carbon delivered to the ocean from terrestrial environments. Solution 255 of the mixing equation $\delta^{13} \mathrm{C}=\mathrm{F}_{\mathrm{t}} \times \delta^{13} \mathrm{C}_{\mathrm{t}}+\mathrm{F}_{\mathrm{m}} \times \delta^{13} \mathrm{C}_{\mathrm{m}}$ (with $\mathrm{F}_{\mathrm{m}}+\mathrm{F}_{\mathrm{t}}=1$ ) provides a 256 simple method for estimating the proportions of the two types of organic matter 257 present in a given sample (Calder and Parker, 1968; Fontugne and Duplessy, 1986; 
258 Fontugne and Jouanneau, 1987). In this equation, $F_{t}$ and $F_{m}$ are the fractions of 259 terrestrial and marine organic matter, and $\delta^{13} C_{t}$ and $\delta^{13} C_{m}$ are the isotopic 260 composition of the terrestrial and marine organic carbon sources, respectively.

261 Following Fontugne and Calvert (1992) and Fontugne et al. (1989), we use $\delta^{13} \mathrm{C}$ 262 values of $-21 \%$ and $-27 \%$ for the marine and terrestrial end-members, respectively. 263 The calculation shows that the terrestrial fraction varies between $75 \%$ and $85 \%$ for 264 KB-06 and between $85 \%$ and $90 \%$ for KBROUS.

5.2 Core timelines

The discharge of solid matter from the Rhône to the sea is characterised by large seasonal and interannual variations; overall, on the order of 2 to 8 million tons per year $\left(\mathrm{Mt}_{\mathrm{yr}} \mathrm{yr}^{-1}\right.$ ), but it can reach up to $26.5 \mathrm{Mt.yr}^{-1}$ (Pont et al., 2002). The high discharge episodes, responsible for about $80 \%$ of the total amount delivered to the coast (Antonelli et al., 2004; Roussiez et al., 2005), occur during floods. Due to the 272 impulsive nature of the discharge of solid matter, but also to the resuspension of surface sediments by storms (Aloisi et al., 1982), the core samples do not reflect a continuous sedimentation process. In addition, other processes such as bioturbation 275 and biological uptake add further complexity to the establisment of a reliable 276 chronology. Therefore, it is beyond the scope of the present study to produce a 277 detailed chronology on which conclusions could be based. Nevertheless, it is very 278 important to place the measured vertical profiles on a time scale to calculate decaycorrected OBT concentrations in each core and thus to obtain OBT levels at the time 280 of deposition. In the following, we use the ${ }^{239,240} \mathrm{Pu}$ and ${ }^{241} \mathrm{Am}$ concentration 281 measurements in the cores along with historical discharges of ${ }^{239,240} \mathrm{Pu}$ by the 282 Marcoule site to infer a simplified chronology for each core assuming an average 
sedimentation rate, as proposed by Lansard (2004). The main interest of these

284 radionuclides is that, apart from the small imprint by the bomb-tests fallouts, they 285 have a unique source in the Rhône river (the Marcoule site); the start of the releases, 286 in the mid-1970's, thus constitutes a convenient tie-point.

\subsubsection{KBROUS core}

The vertical distribution of ${ }^{239,240} \mathrm{Pu}$ in the KBROUS core is reported by Lansard et al., 2007. The primary source of plutonium measured in the sediments near the Rhône mouth originates from the liquid effluents released by the Marcoule reprocessing plant. The chronology of these discharges is available from Eyrolle et al., 2004. The visual comparison of the ${ }^{239,240} \mathrm{Pu}$ profile with the history of plutonium 294 liquid discharges from the Marcoule site allows us to estimate a mean sedimentation 295 rate of 0.186 m.yr ${ }^{-1}$ (Fig. 6). This average sediment accumulation rate is in good agreement with that determined by Lansard (2004) who concludes, based on the

297 historical release of ${ }^{239,240} \mathrm{Pu}$ from Marcoule, that the average sedimentation rate for 298 KBROUS over the last forty years is of the order of $0.17 \mathrm{~m} . \mathrm{yr}-1$

\subsubsection{KB-06 core}

In the KB-06 core the vertical distribution of ${ }^{241} \mathrm{Am}$, an other artificial radionuclide released along with plutonium by Marcoule military activities, was measured by IRSN 303 (unpublished results). The history of ${ }^{241} \mathrm{Am}$ discharges from the Marcoule site can be 304 reconstructed from that of ${ }^{239,240} \mathrm{Pu}$ (Eyrolle et al., 2004) using the good correlation 305 between ${ }^{239,240} \mathrm{Pu}$ and ${ }^{241} \mathrm{Am}$ observed in the KBROUS core (Fig. 7) and assuming 306 that, since both radionuclides have the same strong affinity for solid particles, the 
${ }^{241} \mathrm{Am} /{ }^{239,240} \mathrm{Pu}$ ratio is not significantly modified between the liquid releases and the

308 deposition in the sediment. From the visual comparison of the ${ }^{241} \mathrm{Am}$ profile with the

309 history of ${ }^{241} \mathrm{Am}$ liquid discharges (Fig. 8), we deduce a mean sedimentation rate of $310 \quad 0.025$ m.yr $r^{-1}$.

\subsection{Time-evolution of the OBT record}

Figure 9 displays the time-evolution of the tritium (OBT) content of the organic matter in the KB-06 and KBROUS cores. For each core, the time scale used is that determined in Section 5.2. The tritium concentrations have been decay-corrected so the OBT content is that of suspended organic matter at the date of deposition. In both

317 cores, tritium concentrations start to increase in the early 1970's and decrease after

318 1990. The chronological agreement between the two OBT profiles of Figure 9 shows

319 that our strategy of using average sedimentation rates gives coherent results in spite

320 of its oversimplification. For the KBROUS core (Fig. 9 black solid line), the higher 321 resolution relative to KB-06 allows us to distinguish two peaks, a first one reaching up 322 to 40,000 TU and a second one with values up to 30,000 TU. For 1986-1987, Gontier 323 et al. (1992) reported a tritium (OBT) value of 26,160 TU in surface sediments (0-3 $324 \mathrm{~cm}$ ) at the mouth of the Rhône. This is fully consistent with the tritium concentrations recorded in the KBROUS core (see Fig. 9). Later on, tritium levels decrease strongly, 326 in agreement with tritium (OBT) measured in suspended matter at Arles in 2010-2011 327 (Jean-Baptiste et al., 2018).

328 The tritium maximum measured in the KB-06 core, 20,000 TU (black dotted line 329 Fig. 9), is lower than that of the KBROUS core. This decrease in tritium as distance 330 from the mouth increases, has already been noted by Gontier et al. (1992). It can be 331 explained by the fact that the size distribution of river suspended matter is shifted 
332 towards larger particles compared to marine suspended matter (Eisma et al., 333 1991; Reynolds et al., 2010). Because of this, river particles tend to settle

334 preferentially close to the river mouth. Therefore, sediments closer to the river mouth 335 are proportionally richer in organic matter of riverine origin (i.e., with a greater tritium 336 content) than sediments further offshore.

\section{Attributing OBT levels in organic matter to the various known sources}

The OBT for the land-based organic material due to atmospheric nuclear tests is

341 of the same magnitude as that for rain. The mean annual tritium content for rain

342 peaks towards 2,000 TU in 1963 at the latitude of France. This figure is far lower than

343 the maximum values recorded for the KBROUS core ( 40,000 TU). This clearly 344 indicates that atmospheric nuclear tests are not the main cause of the peak in tritium 345 recorded in the Rhône prodelta.

\subsection{Liquid tritium discharges}

The OBT content of the organic matter at the surface of the KBROUS core

349 (corresponding to year 2001) was $1855 \pm 200$ TU for a total annual liquid discharge of 200.8 TBq (Fig. 3). With the mean flow rate of the Rhône being $1700 \mathrm{~m}^{3} \mathrm{~s}^{-1}$, this

351 discharge corresponds to an elevation of the tritium content of the river water of

$35231.4 \mathrm{TU}$. In comparison, on the Loire river (mean flow rate $=850 \mathrm{~m}^{3} \mathrm{~s}^{-1}$ ), where four nuclear electricity production sites are in operation with total annual liquid tritium

354 discharges of about $150 \mathrm{TBq}$ (EDF, 2007), the OBT level in sediments downstream of the nuclear plants in 2003 was only 55 TU (Gontier and Siclet, 2011), in spite of a 
356 higher mean elevation of the tritium content of the river water (47 TU). The maximum

357 of the liquid discharge of tritium (HTO) to the Rhône reaches $1000 \mathrm{TBq}$ (Fig. 3),

358 corresponding to an additional tritium content of the river waters of 156 TU. Scaled to

359 the Loire river data, a tritium level in the organic matter on the order of 183 TU should

360 be expected. This value is far from the maximum values $(40,000 \mathrm{TU})$ recorded in the

361 KBROUS core. These comparisons with the Loire river data clearly indicate that the

362 liquid tritium discharges cannot be held responsible for the high values of tritium

363 recorded in the Rhône prodelta. This fact is corroborated by the close examination of

364 the data which reveals that, whereas the tritium discharges start to increase again

365 after 1998 (with an increase by $70 \%$ between 1998 and 2010 - Fig. 3), the tritium 366 content of sediments decreases continuously (Fig. 9), thus indicating that the two 367 records are not correlated.

6.3 Gaseous tritium discharges

We have seen (Section 3.3.1) that gaseous tritium (HTO) discharged into the 371 atmosphere later appears in the land-based environment. The two largest emitters of 372 tritium into the atmosphere are the CEA-Valduc and Marcoule sites. Environmental data gathered around these sites (Section 3.3.1) show that these releases have a very significant effect on the local land vegetation. However, the global influence at 375 the scale of the Rhône watershed, and therefore on the organic matter transferred to 376 the river, remains to be quantified. In the study into the influence of tritium gaseous 377 discharges on the environment around the Bruyère-le-Châtel nuclear site operated 378 by CEA, Baglan et al. (2011) demonstrated that the tritium content in the land-based 379 organic material decreases with distance following an exponential rule described by 380 the formula: 


$$
(T / H)=(T / H)^{0}+(T / H)^{\max } \exp \left(-r / r_{0}\right)
$$

382 where $r$ is the distance, $(\mathrm{T} / \mathrm{H})^{\mathrm{max}}$ is the value in the immediate environment of the 383 source of the discharge (corresponding to $r=0$ ) and $(T / H)^{0}$ is the value from 384 background noise. Baglan et al. (2011) suggest a value for ro equal to $0.8 \mathrm{~km}$. 385 Applied to the data obtained around Marcoule in 2008-2011 by Roussel-Debet 386 (2012), it is noted that this value is satisfactory for the local environment, but 387 minimises the influence of discharges beyond a few kilometres (Fig. 10). The data for 388 Marcoule is better described using a linear combination of two exponentials, one as near-field with an $r_{0}$ of $0.8 \mathrm{~km}$ and a second with an $r_{0}^{\prime}$ equal to $8 \mathrm{~km}$ which increases 390 the distance influenced by the discharge to $60-80 \mathrm{~km}$ :

$$
(T / H)=(T / H)^{0}+(T / H)^{\max }\left[\exp \left(-r / r_{0}\right)+0.1 \exp \left(-r / r_{0}^{\prime}\right)\right]
$$

392 with $(T / H)^{\max }=30,000 \mathrm{TU}$. Over the same period $2008-2011$, the mean value for gaseous tritium discharge from Marcoule was $D^{\top}=302$ TBq. $y r^{-1}$.

394 The mean value for year $n$ of the tritium added to the land vegetation by the 395 gaseous tritium releases $D_{n}^{\top}$ can therefore be written :

$$
(T / H)_{n}=A^{-1}(T / H)_{n}{ }^{\max } \int_{0}^{\infty}\left[\exp \left(-r / r_{0}\right)+0.1 \exp \left(-r / r_{0}^{\prime}\right)\right] 2 \pi r d r
$$

397 where $A$ is the total surface area of the Rhône watershed $\left(A \sim 100000 \mathrm{~km}^{2}\right)$. Since 398 formula (3) implies that $(T / H)_{n}{ }^{m a x}$ is proportional to the annual discharge $D_{n}^{\top}$, $399(\mathrm{~T} / \mathrm{H})_{n}{ }^{\max }$ can be expressed as $(T / H)_{n}{ }^{\max }=\alpha D_{n}^{\top}$, with $\alpha=30,000 / 302$ by reference to 400 the situation around Marcoule in 2008-2011.

401 Solving the integral in formula (3) leads to :

$$
(T / H)_{n}=2 \pi A^{-1} \alpha D_{n}^{\top} \times\left[r_{0}^{2}+0.1 r_{0}^{\prime 2}\right]
$$


Finally, the mean tritium content of land vegetation for the whole Rhône catchment under the influence of the gaseous discharges from both Marcoule and 405

Valduc for the year $n$ can be expressed as:

$$
(\mathrm{T} / \mathrm{H})_{\mathrm{n}}^{\text {total }}=(\mathrm{T} / \mathrm{H})_{\mathrm{n}}^{0}+(\mathrm{T} / \mathrm{H})_{\mathrm{n}}{ }^{\text {Marcoule }}+(\mathrm{T} / \mathrm{H})_{\mathrm{n}} \text { Valduc }
$$

The peak value for the tritium gaseous discharges by Marcoule and Valduc occurred around 1974 with $8600 \mathrm{TBq}$ and $38800 \mathrm{Tbq}$ respectively (Fig. 2). This corresponds to $(\mathrm{T} / \mathrm{H})_{1974^{\text {Marcoule }}}=378 \mathrm{TU}$ and $(\mathrm{T} / \mathrm{H})_{1974}^{\text {Valduc }}=1704 \mathrm{TU}$. Taking $(\mathrm{T} / \mathrm{H})^{0}{ }_{1974}=100 \mathrm{TU}$ (IAEA database at https://nucleus.iaea.org /wiser/gnip.php), the mean tritium content for the land vegetation of the whole Rhône catchment under the influence of the discharges of Marcoule and Valduc at their historical peak of 1974 amounts to $2182 \mathrm{TU}$. This value represents about $5 \%$ of the tritium peak value recorded in the KBROUS core. Moreover, this estimate is probably an upper limit for the following reasons:

- The function describing the decreasing influence of the discharge with the distance was deliberately chosen as an envelope curve.

- The integration over $360^{\circ}$ is certainly an overestimation as the wind rose has a very pronounced directional element: at the Marcoule site for example, the wind (Mistral) blows from the north more than half of the time.

- A substantial proportion of the gaseous discharges from Valduc enters the River Seine basin.

- The calculation does not take into account the smoothing effect caused by the fact that the residence time of the organic matter in the land vegetation is greater than one year.

This probable overestimation by formula (5) is consistent with the fact that, in the case of Valduc, the comparison of the tritium contents of the sediments in the Rhône 
428 downstream of Le Bugey power station and upstream of Saint Alban power station

429 (Gontier and Siclet, 2011) reveals no anomaly associated with the confluence of the

430 Saône (see Fig. 1). With regard to Marcoule, the tritium contents measured in the 431 sediments of the Rhône at the level of Tricastin power station (Gontier and Siclet,

432 2011) are similar to those measured in the prodelta. As Tricastin is to the north of the

433 Marcoule site and therefore little influenced by its discharges (Roussel-Debet, 2012), 434 this again suggests, as with the case of Valduc, that the imprint of gaseous 435 discharges from Marcoule in the sediments is masked by a much larger signal. This 436 inevitably points to the legacy of the past use of tritiated luminous paints by the 437 watchmaking industry in the upper Rhône area.

438 As already pointed out in Section 3.3.4, the tritium anomaly in the upstream sediments of the Rhône, attributed to the watchmaking industry, is still very 440 pronounced, with maximum values in the range $10^{5}$ to $10^{6}$ TU between $2002-2005$ 441 near to the Swiss border (Jean-Baptiste et al., 2007). This shows that there is still a 442 considerable amount of tritium stored in the upstream Rhône sediments. This 443 quantity of stored sediment, whose tritium-contaminated particulate matter moves 444 from upstream to downstream particularly when the dams are flushed (every three 445 years from the 1970 s until 2003), has a very high $\mathrm{T} / \mathrm{H}$ ratio. Due to its scale, this 446 contamination of the Rhône sediments seems capable by itself of explaining what 447 lies behind the peak in tritium recorded in the prodelta sediments, masking all other 448 sources of tritium.

\section{Conclusion}

Tritium (OBT) and carbon-14 levels in suspended organic matter carried by the

452 Rhône over the period 1970-2001 were obtained based on the study of two sediment 
453

cores collected in the sedimentary cone off the river mouth. The main conclusions of the present work are as follows:

- Measured tritium and carbon-14 concentrations display a peak commencing at the start of the 1970s and extending over some thirty years.

- The source of the carbon-14 peak is difficult to establish due to the fact that carbon-14 releases by the nuclear industry are unknown (until recently, carbon-14 releases were not recorded separately from other beta/gamma emitters). However, it appears that a significant contribution from the carbon-14 bomb-peak may have been captured in the sedimentary record. Anyway, carbon-14 levels remain low (below the modern carbon-14 natural value of $100 \mathrm{pmC}$ ) because of the diluting effect of a refractory carbon component very low in carbon-14 present in the coastal sediments.

- Organically bound tritium levels are more pronounced, with maximum values up to 40,000 TU (i.e., 20 times the tritium peak of the atmospheric nuclear tests of the 1950 's and early 1960's).

- Detailed study of the impact of the various contributions to the OBT seen in the sedimentary record strongly suggests that these high tritium levels cannot be explained neither by the bomb-peak nor by the releases of the nuclear industry but are the result of the sediments in the Rhône being contaminated from upstream to downstream by the past utilisation of tritiated luminous paints by the watchmaking industry. This contamination is at its highest in the upper Rhône, upstream of Creys Malville, the northernmost nuclear power station on the Rhône. Its influence, which is well documented all along the river, masks all other sources of tritium and seems capable by itself of explaining what lies behind the peak in tritium recorded in the prodelta sediments. 


\section{References}

479 Aloisi J.C., Cambon J.P., Carbonne J., Cauwet G., Millot C., Monaco A. and Pauc H. (1982) Origin and role of the bottom nepheloid layer in the transfer of particles into the marine environment. Application to the Gulf of Lions. Oceanologica Acta

Antonelli C., Provansal M. and Vella C. (2004) Recent morphological channel changes in a deltaic environment. The case of the Rhone River, France. Geomorphology 57, 385-402.

Baglan, N., Alanic, G., Le Meignen, R., Pointurier, F. (2011) A follow-up of the decrease of non-exchangeable organically bound tritium levels in the surroundings of a nuclear research center. J. Environ. Radioact. 102, 695-702.

Bentaleb I., Fontugne M. (1996) Anthropogenic $\mathrm{CO}_{2}$ invasion of the surface Ocean: its influence on the organic carbon isotope composition of phytoplankton. C.R.Acad. Sci., Paris, Ser. Ila, 322, 743-748.

Calder, J. A. and Parker, P. L. (1968) Stable carbon isotope ratio as indices of petrochemical pollution of aquatic systems. Environ. Sci. Technol., 2 , 535-539.

Cathalot, C., Rabouille, C., Tisnérat-Laborde, N., Toussaint, F., Kerhervé, P., Buscail, R., Loftis, K., Sun, M.Y., Tronczynski, J., Azoury, S., Lansard, B., Treignier, C., Pastor, L., Tesi, T. (2013) The fate of river organic carbon in coastal areas: $\mathrm{A}$ study in the Rhône river delta using multiple isotopic $\left(\delta^{13} \mathrm{C}\right.$, $\Delta^{14} \mathrm{C}$ ) and organic tracers. Geochimica et Cosmochimica Acta 118, 33-55.

Cauquoin, A., Jean-Baptiste, P., Risi, C., Fourré, E., Stenni, B., Landais, A. (2015) The global distribution of natural tritium in precipitation simulated with an 
Atmospheric General Circulation Model and comparison with observations. Earth Planet. Sci. Lett. 427, 160-170.

503 Charmasson S. (2003) ${ }^{137}$ Cs inventory in sediment near the Rhone mouth: role 504 played by different sources. Oceanologica Acta $26,435-441$.

505 Charmasson S., Bouisset P., Radakovitch O., Pruchon A.S., Arnaud M. (1998) Longcore profiles of ${ }^{137} \mathrm{Cs},{ }^{134} \mathrm{Cs},{ }^{60} \mathrm{Co}$ and ${ }^{210} \mathrm{~Pb}$ in sediment near the Rhone River (Northwestern Mediterranean Sea). Estuaries 21, 367-378.

508 Clarke, W.B., Jenkins, W.J., Top, Z. (1976) Determination of tritium by mass spectrometry measurement of ${ }^{3} \mathrm{He}^{+}$. Int. J. Appl. Radiat. Isot. 27, 515 - 522.

510 Daillant, O., Pigrée, G., Gueidan, C., Jacquiot, L. (2001) Recherche de tritium 511 organiquement lié dans les lichens des environs de Valduc. Rapport de 512 l'Observatoire Mycologique pour la Structure d'Echange et d'Information sur $513 \quad$ Valduc (SEIVA), Observatoire Mycologique, F-71250 Mazille.

514 EDF (Electricité de France) (2007) Nucléaire \& Environnement 2007 Report, 36pp.

515 Eisma, D., Bernard, P., Cadée, G.C., Ittekkott, V., Kalf, J., Laane, R., Martin, J.M., 516 Mook, W.G., Van Put, A., Schuhmacher, T. (1991) Suspended-matter particle 517 size in some west-european estuaries: Part I: particle size distribution. $518 \quad$ Netherlands Journal of Sea Res. 28, 193-214.

519 Eyrolle F., Charmasson S., Louvat D. (2004) Plutonium isotopes in the lower 520 reaches of the River Rhone over the period 1945-2000: fluxes towards the 521 Mediterranean Sea and sedimentary inventories. J. Environ. Radioact. 72, 273522 286. 
523 Eyrolle-Boyer, F., Boyer, P., Claval, D., Charmasson, S. (2014) Apparent enrichment of organically bound tritium in rivers explained by the heritage of our past. J. Environ. Radioact. 136, 162-168.

Eyrolle, F., Ducros, L., Le Dizès, S., Beaugelin-Seiller, K., Charmasson, S., Boyer, P., Cossonnet, C. (2018) An updated review on tritium in the environment. J. Environ. Radioact. 181, 128-137.

Fontugne M. and Jouanneau J.M. (1987) Modulation of the particulate organic carbon flux to the ocean by a macrotidal estuary: organic carbon isotopes

Fontugne M., Paterne M., Calvert S.E., Murat A., Guichard F., Arnold M. (1989) Adriatic deep warer formation during the Holocene. Implication for the re-

Fontugne M. and Calvert S.E. (1992) Late Pleistocene variability of the carbon oxygenation of the deep eastern Mediterranean Sea. Paleoceanography 4, 199206.

Friedly H., Lötscher H., Oeschger, H., Siegenthaler U., Stauffer, B. (1986) Ice core record of the ${ }^{13} \mathrm{C} /{ }^{12} \mathrm{C}$ ratio of the atmospheric $\mathrm{CO}_{2}$ in the two past centuries.

543 Gauthier C. and Hatté, C. (2008) Effects of handling, storage and chemical 544 treatments on ${ }^{13} \mathrm{C}$ values of continental sediments. Geochem. Geophys. Geosyst., 9(8), Q08011, doi:10.1029/2008GC001967. 
546 Gontier, G., Grenz, C., Calmet, D., Sacher, M. (1992) The contribution of Mytilus sp. in radionuclide transfer between water comlumn and sediments in the estuarine and delta systems of the Rhône River. Estuarine Coastal Shelf Sci. 34, 593-601.

Gontier, G. and Siclet, ,F. (2011) Organic tritium in freshwater ecosystems: long-term trends in the environment of French nuclear power plants. Radioprotection 46, $457-491$.

Guétat, P., Le Goff, P., Boyer, C., Duda, J.M. (2013) Apports de la surveillance du centre CEA-Valduc sur la connaissance des transferts de l'eau tritiée atmosphérique dans les différents compartiments de l'environnement. Radioprotection 48, 367-389.

Harmelin-Vivien, M., Dierking, J., Banaru, D., Fontaine, M.F., Arlhac, D. (2010) Seasonal variation in stable $\mathrm{C}$ and $\mathrm{N}$ isotope ratios of the Rhone River inputs to the Mediterranean Sea (2004-2005). Biogeochemistry 100, 139-150.

Hatté, C., Poupeau, J.J., Tatman, J.F., Paterne, M. (2003) Development of an automated system for preparation of organic samples. Radiocarbon 45, 421-430.

Jean-Baptiste, P., Andrié , C., Lelu, M. (1989) The diffusion of helium through glass. Glass Technol. 30, 228-230.

Jean-Baptiste, P., Baumier, D., Fourré, E., Dapoigny, A., Clavel, B. (2007) The distribution of tritium in the terrestrial and aquatic environments of the CreysMalville nuclear power plant (2002-2005). J. Environ. Radioact. 94, 107-118.

Jean-Baptiste, P., Fourré, E., Dapoigny, A., Baumier, D., Baglan, N., Alanic, G. (2010) ${ }^{3} \mathrm{He}$ mass spectrometry for very low-level measurement of organic tritium in environmental samples. J. Environ. Radioact. 101, 185-190. 
569 Jean-Baptiste, P., Fontugne, M., Fourré, E., Marang, L., Antonelli, C., Charmasson, S., Siclet, F. (2018) Tritium and radiocarbon levels in the Rhône river delta and along the French Mediterranean coastline. J. Environ. Radioact. 187, 53-64.

572 Krejci, K. and Zeller, A. (1979) Tritium pollution in the Swiss luminous compound industry. In: Behaviour of tritium in the Environment. IAEA Proceedings series

575 Lansard B., Charmasson, S., Gascó, C., Antón, M.P., Grenz, C., Arnaud, M. (2007) Spatial and temporal variations of plutonium isotopes $\left({ }^{238} \mathrm{Pu}\right.$ and $\left.{ }^{239,240} \mathrm{Pu}\right)$ in sediments off the Rhone River mouth (NW Mediterranean). Sci. Total Environ. $376,215-227$.

Lansard, B. (2004) Distribution et remobilisation du Plutonium dans les sédiments du prodelta du Rhône (Méditerranée Nord-Occidentale). PhD thesis, Université de la Méditerranée Aix-Marseille II, pp.279.

Lansard, B., Rabouille, C., Denis, L., Grenz, C. (2009) Benthic remineralization at the land-ocean interface: A case study of the Rhône River (NW Mediterranean Sea). Estuarine Coastal Shelf Sci. 81, 544-554.

Le Guen, B., Siclet, F. (2009) Impact du carbone-14 autour des centrales nucléaires EDF. Radioprotection 44, 495-504.

Monaco, A., Courp, T., Heussner, S., Carbonne, J., Fowler, S.W., Deniaux, B. (1990) Seasonality and composition of particulate fluxes during ECOMARGE-I, western Gulf of Lions. Cont. Shelf Res. 10, 959-987.

Mook, W.G. and van der Plicht, J. (1999) Reporting C-14 activities and concentrations. Radiocarbon 41, 227-239. 

613

Nydal, R. and Lövseth, K. (1996) Carbon-14 Measurements in Atmospheric $\mathrm{CO}_{2}$ from Northern and Southern Hemisphere Sites, 1962-1993. ORNL/CDIAC-93, NDP057. Carbon Dioxide Information Analysis Center, Oak Ridge National Laboratory, Oak Ridge, Tennessee. 67 pp. doi: 10.3334/CDIAC/atg.ndp057

Pont, D., Simonnet, J.P., Walter, A.V. (2002) Medium-term changes in suspended sediment delivery to the ocean: Consequences of catchment heterogeneity and river management (Rhone River, France). Estuarine Coastal Shelf Sci. 54 (1), 118.

Radakovitch O., Charmasson S., Arnaud M. and Bouisset P. (1999) ${ }^{210} \mathrm{~Pb}$ and caesium accumulation in the Rhône delta sediment. Estuarine Coastal Shelf Sci. 48, 77-99.

Reynolds, R.A., Stramski, D., Wright, V.M., Wozniak, S.B. (2010) Measurements and characterisation of particle size distributions in coastal waters. J. Geophys. Res. 115, C08024, doi: 10.1029/2009JC005930.

Roussel-Debet, S. (2012) Constat radiologique Vallée du Rhône. Rapport final relatif au milieu terrestre. Rapport IRSN PRP-ENV/SESURE/2012-06.

Roussiez V., Aloisi J. C., Monaco A. and Ludwig W. (2005) Early muddy deposits along the Gulf of Lions shoreline: a key for a better understanding of land-to-sea transfer of sediments and associated pollutant fluxes. Mar. Geol. 222, 345-358.

Trundinger C.M., Enting I.G., Francey R.J., Etheridge D.M., Rayner P.J. (1999) 12 Long-term variability in the global carbon cycle inferred from a high-precision $\mathrm{CO}_{2}$ and $\delta^{13} \mathrm{C}$ ice-core record. Tellus $\mathrm{B} 51,233-248$. 


\section{Figure captions}

615 Figure 1: Location of main nuclear activities in the Rhône catchment: power stations

616 (in red) operated by Electricité de France (EDF) and nuclear facilities (in blue)

617 operated by the French Atomic Energy Commission (CEA) and the AREVA 618 company. Inset: location of the KBROUS and KB-06 cores taken in November 2001.

619 Figure 2: Tritium (HTO) airborne releases (Jean-Baptiste et al., 2018). Dotted curve:

620 Marcoule releases. Solid curve: cumulative releases from Marcoule and Valduc.

621 Figure 3: Tritium liquid releases (Jean-Baptiste et al., 2018). Dotted curve: Marcoule 622 releases. Solid black curve: cumulative releases from Marcoule and EDF nuclear 623 power stations. Blue curve: cumulative releases from Marcoule, EDF nuclear power 624 stations and indirect inputs to the Rhône by the contamination of the hydrographic 625 network by tritium airborne releases (see Section 3.3.3).

626 Figure 4: Spatial distribution of the tritium (OBT) content of sediments along the 627 Rhône in 2004-2005 (Gontier \& Siclet, 2011).

628 Figure 5: Profiles of organically bound tritium (OBT) (in black) and carbon-14 (in blue) 629 in the organic matter of (a) the KB-06 and (b) the KBROUS sediment core samples 630 collected in 2001 at the mouth of the Rhône.

631 Figure 6: Comparison between the history of ${ }^{239,240} \mathrm{Pu}$ discharges from the Marcoule

632 site (Eyrolle et al., 2004) and the vertical distribution of ${ }^{239,240} \mathrm{Pu}$ in the KBROUS core 633 (Lansard et al., 2007) for a constant sedimentation rate of $0.186 \mathrm{~m} \cdot \mathrm{yr}^{-1}$.

634 Figure 7: Correlation between ${ }^{239,240} \mathrm{Pu}$ and ${ }^{241} \mathrm{Am}$ (in Bq. $\mathrm{kg}^{-1}$ of dry sediment) for the 635 KBROUS core $\left({ }^{241} \mathrm{Am}\right.$ data are from the Institute of Radioprotection and Nuclear 636 Safety - IRSN). 
637 Figure 8: Comparison between the history of ${ }^{241} \mathrm{Am}$ discharges from the Marcoule 638 site and the vertical distribution of ${ }^{241} \mathrm{Am}$ in the $\mathrm{KB}-06$ core for a constant 639 sedimentation rate of $0.025 \mathrm{~m} . \mathrm{yr}^{-1}\left({ }^{241} \mathrm{Am}\right.$ data are from IRSN).

640 Figure 9: Time-evolution of the tritium content of the organic matter (OBT) in the

641 KBROUS (solid black curve) and KB-06 (dotted black curve) cores. Red rectangle:

642 OBT in a surface sediment $(0-3 \mathrm{~cm})$ from the mouth of the Rhône in 1986-1987 by

643 Gontier et al., 1992; Red crosses: tritium content of suspended matter at Arles in 644 2010-2011 (Jean-Baptiste et al., 2018).

645 Figure 10: Organically bound tritium (OBT) for land vegetation in the environment

646 around Marcoule with the distance to the source of tritium discharges into the

647 atmosphere (Roussel-Debet, 2012). The black curve represents the exponential

648 decrease proposed by Baglan et al. (2011) to explain the data around the CEA site of 649 Bruyère-le-Châtel. The red curve is the one adopted for this study (see Section 6.3). 


\section{Table captions}

651 Table 1: Tritium, carbon-14 and $\delta^{13} \mathrm{C}$ measurements in the KBROUS sediment core.

$652{ }^{241} \mathrm{Am}$ and ${ }^{239,240} \mathrm{Pu}$ data (in Bq. $\mathrm{kg}^{-1}$ of dry sediment) are from the IRSN database and 653 Lansard et al. (2007), respectively.

654

655 Table 2: Tritium, carbon-14 and $\delta^{13} \mathrm{C}$ measurements in the KB-06 sediment core. $656{ }^{241} \mathrm{Am}$ data (in Bq. $\mathrm{kg}^{-1}$ of dry sediment) are from the IRSN database. 


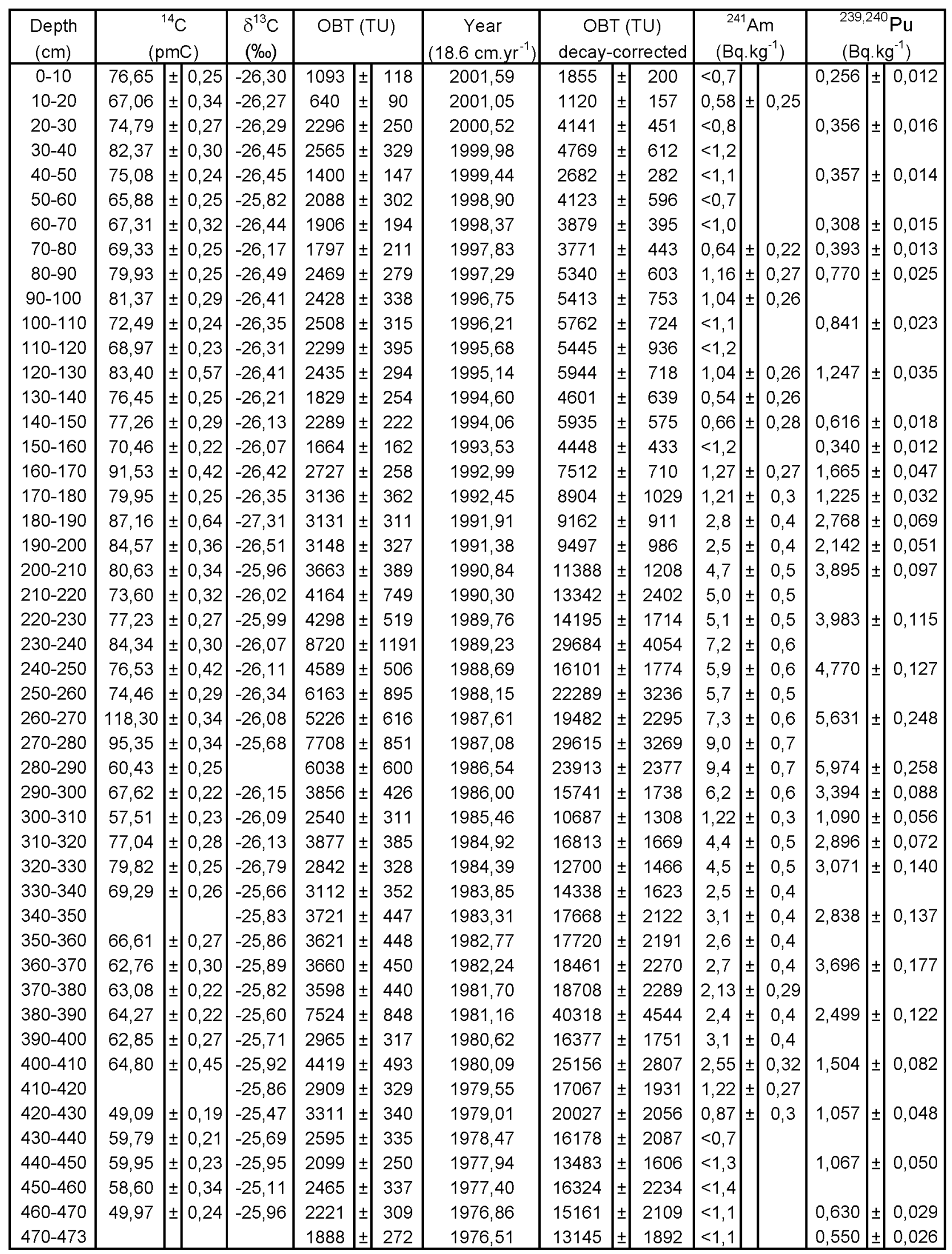




\begin{tabular}{|c|c|c|c|c|c|c|c|c|c|c|c|c|c|c|}
\hline $\begin{array}{l}\text { Depth } \\
(\mathrm{cm})\end{array}$ & \multicolumn{3}{|c|}{$\begin{array}{c}{ }^{14} \mathrm{C} \\
(\mathrm{pmC}) \\
\end{array}$} & $\begin{array}{l}\delta^{13} \mathrm{C} \\
(\% \circ) \\
\end{array}$ & \multicolumn{3}{|c|}{ OBT (TU) } & $\begin{array}{c}\text { Year } \\
\left(2.5 \mathrm{~cm} \mathrm{yr}^{-1}\right) \\
\end{array}$ & \multicolumn{3}{|c|}{$\begin{array}{c}\text { OBT (TU) } \\
\text { decay-corrected }\end{array}$} & \multicolumn{3}{|c|}{$\begin{array}{c}{ }^{241} \mathrm{Am} \\
\left(\mathrm{Bq} \cdot \mathrm{kg}^{-1}\right)\end{array}$} \\
\hline $0-10$ & 59,61 & \pm & 0,22 & $-26,33$ & 1212 & \pm & 153 & 1999,86 & 2269 & \pm & 287 & & & \\
\hline $10-20$ & 61,76 & \pm & 0,25 & $-26,70$ & 2020 & \pm & 279 & 1995,86 & 4734 & \pm & 653 & & & \\
\hline $20-30$ & 79,98 & \pm & 0,30 & $-26,32$ & 1921 & \pm & 237 & 1991,86 & 5640 & \pm & 695 & 0,71 & \pm & 0,27 \\
\hline $30-40$ & 74,44 & \pm & 0,25 & $-26,58$ & 4272 & \pm & 505 & 1987,86 & 15703 & \pm & 1857 & 3,70 & \pm & 0,40 \\
\hline $40-50$ & 77,70 & \pm & 0,26 & $-26,19$ & 3583 & \pm & 485 & 1983,86 & 16497 & \pm & 2233 & 4,40 & \pm & 0,50 \\
\hline $50-60$ & 62,98 & \pm & 0,24 & $-26,32$ & 3380 & \pm & 424 & 1979,86 & 19489 & \pm & 2446 & 1,69 & \pm & 0,21 \\
\hline $60-70$ & 53,77 & \pm & 0,24 & $-25,97$ & 2201 & \pm & 288 & 1975,86 & 15897 & \pm & 2083 & 1,16 & \pm & 0,29 \\
\hline $70-80$ & 41,62 & \pm & 0,20 & $-25,82$ & 397 & \pm & 58 & 1971,86 & 3592 & \pm & 522 & 0,68 & \pm & 0,16 \\
\hline $80-90$ & 36,65 & \pm & 0,20 & $-26,46$ & 24 & \pm & 9 & 1967,86 & 276 & \pm & 102 & 0,52 & \pm & 0,23 \\
\hline $90-100$ & 41,14 & \pm & 0,19 & $-25,59$ & 19 & \pm & 7 & 1963,86 & 262 & \pm & 102 & & & \\
\hline $100-110$ & 34,99 & \pm & 0,18 & $-25,11$ & - & & & 1959,86 & - & & & & & \\
\hline $110-120$ & 39,60 & \pm & 0,19 & $-25,51$ & - & & & 1955,86 & - & & & & & \\
\hline
\end{tabular}




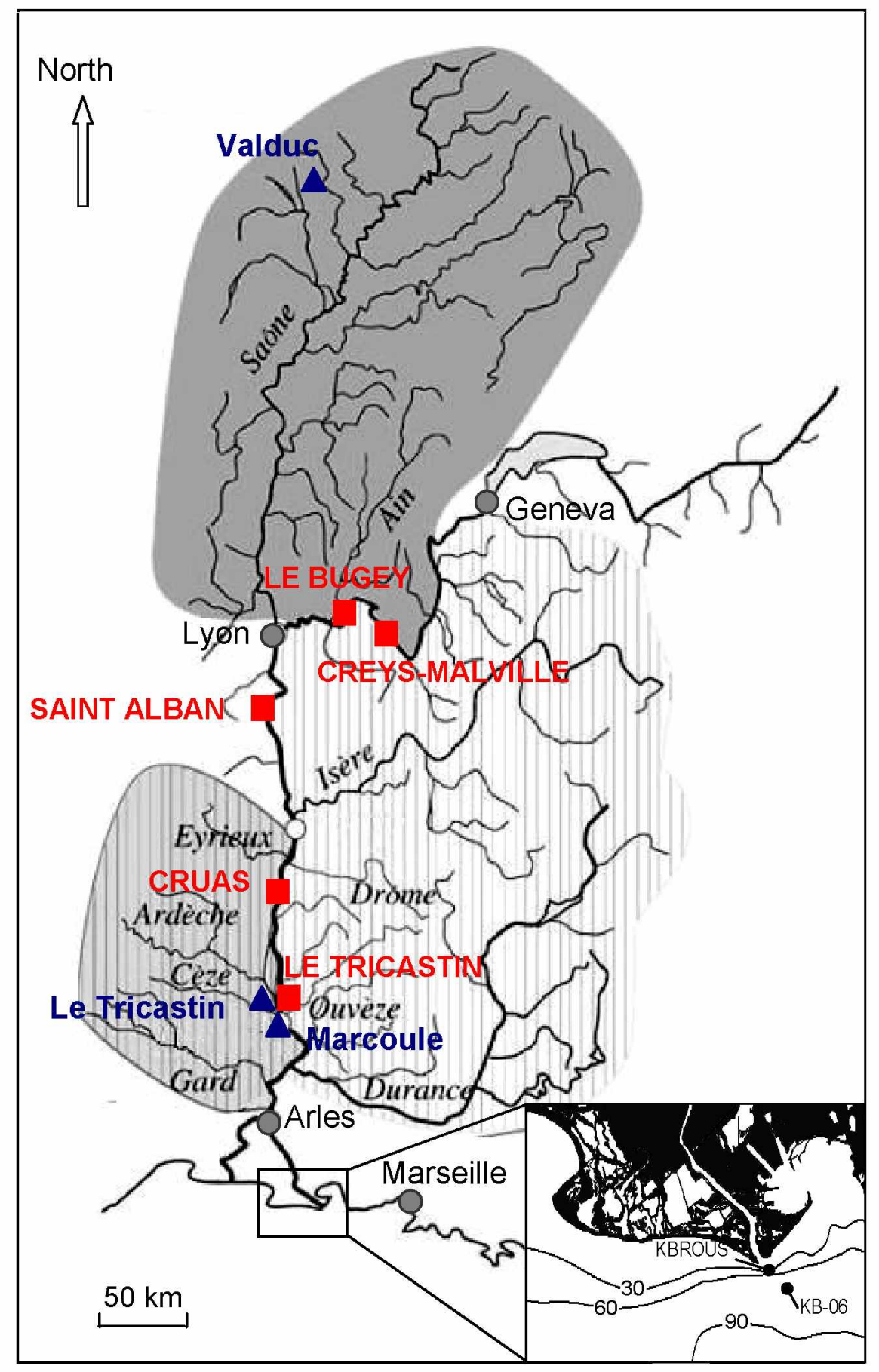

Figure 1 


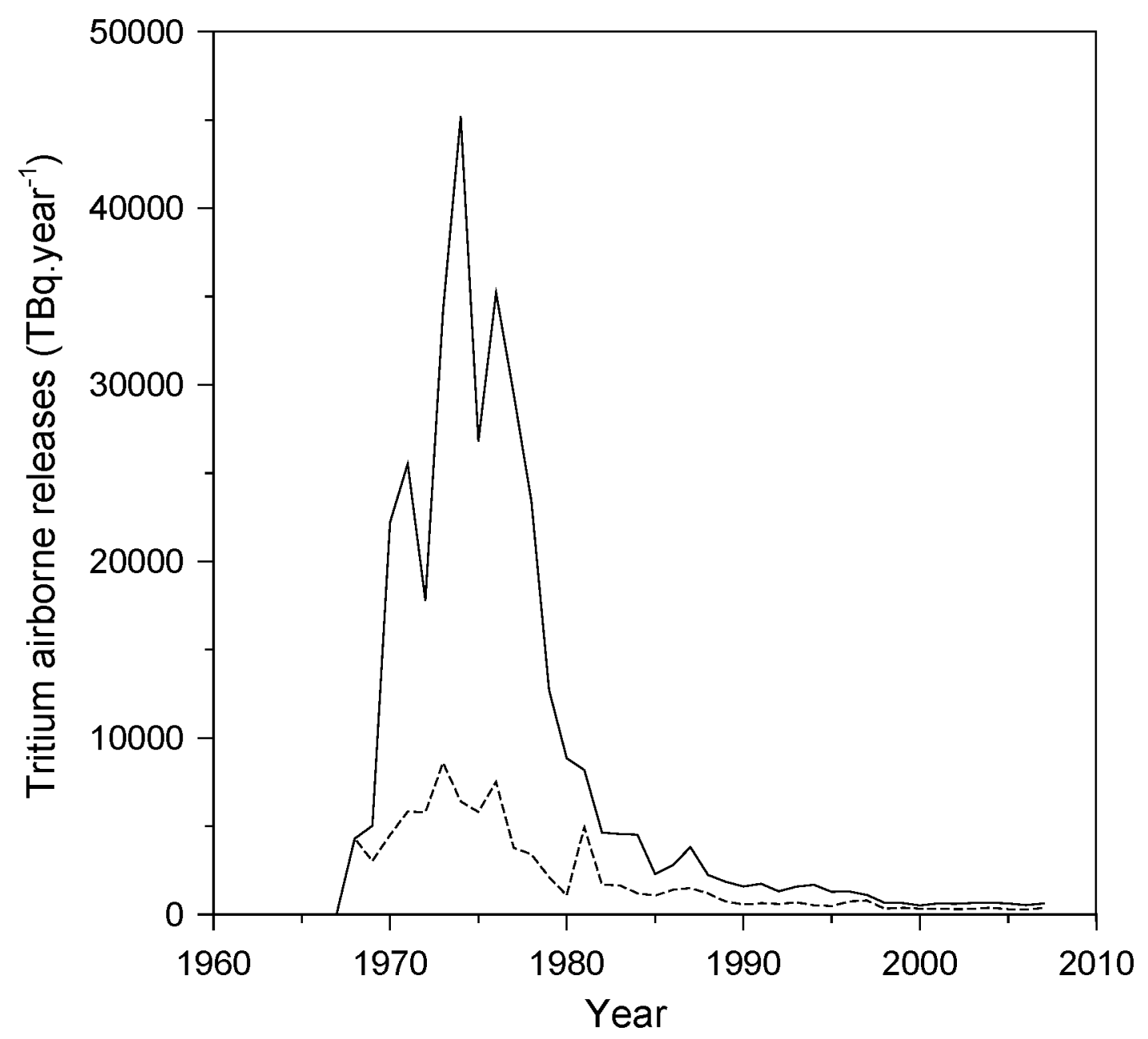




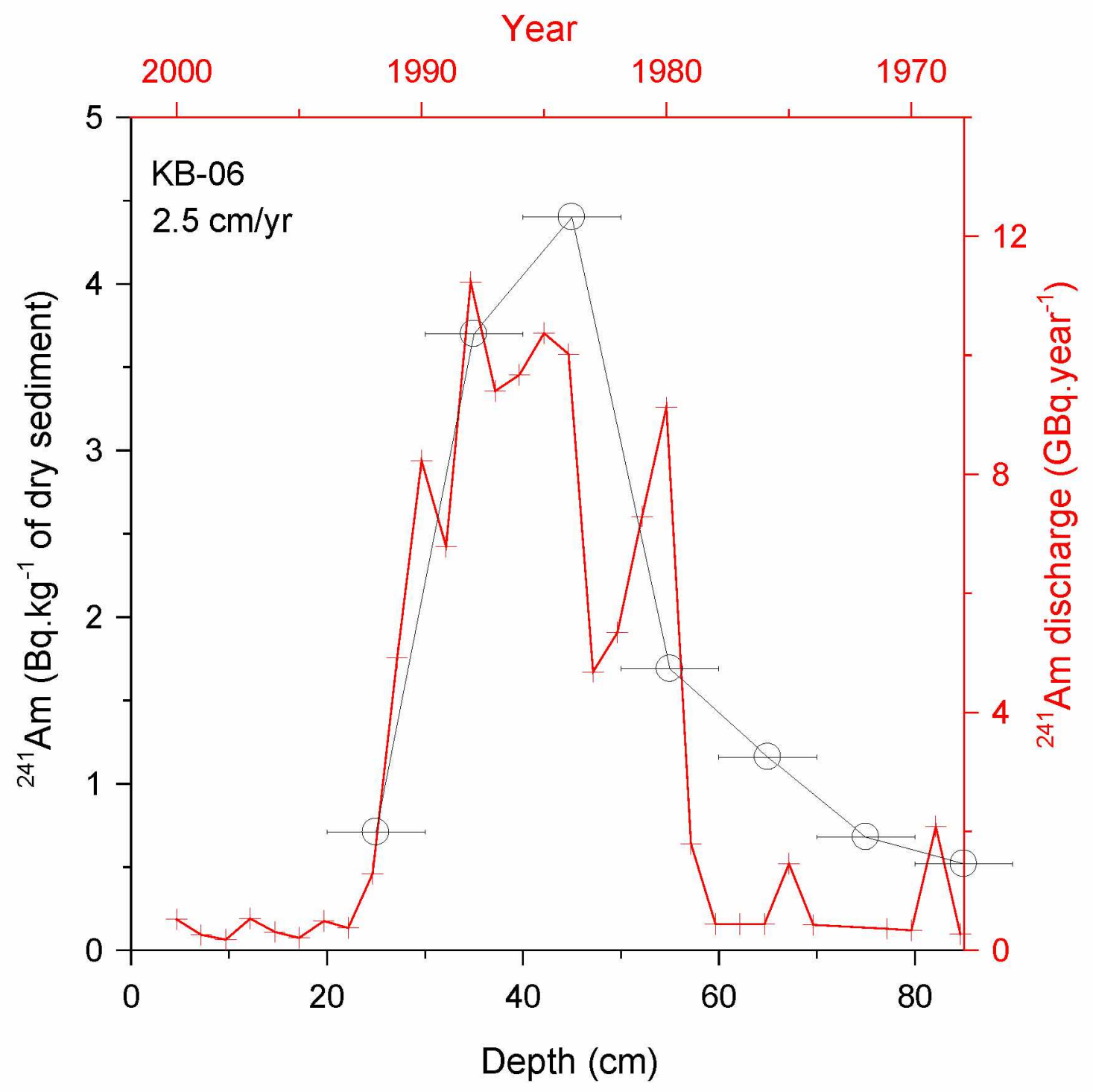




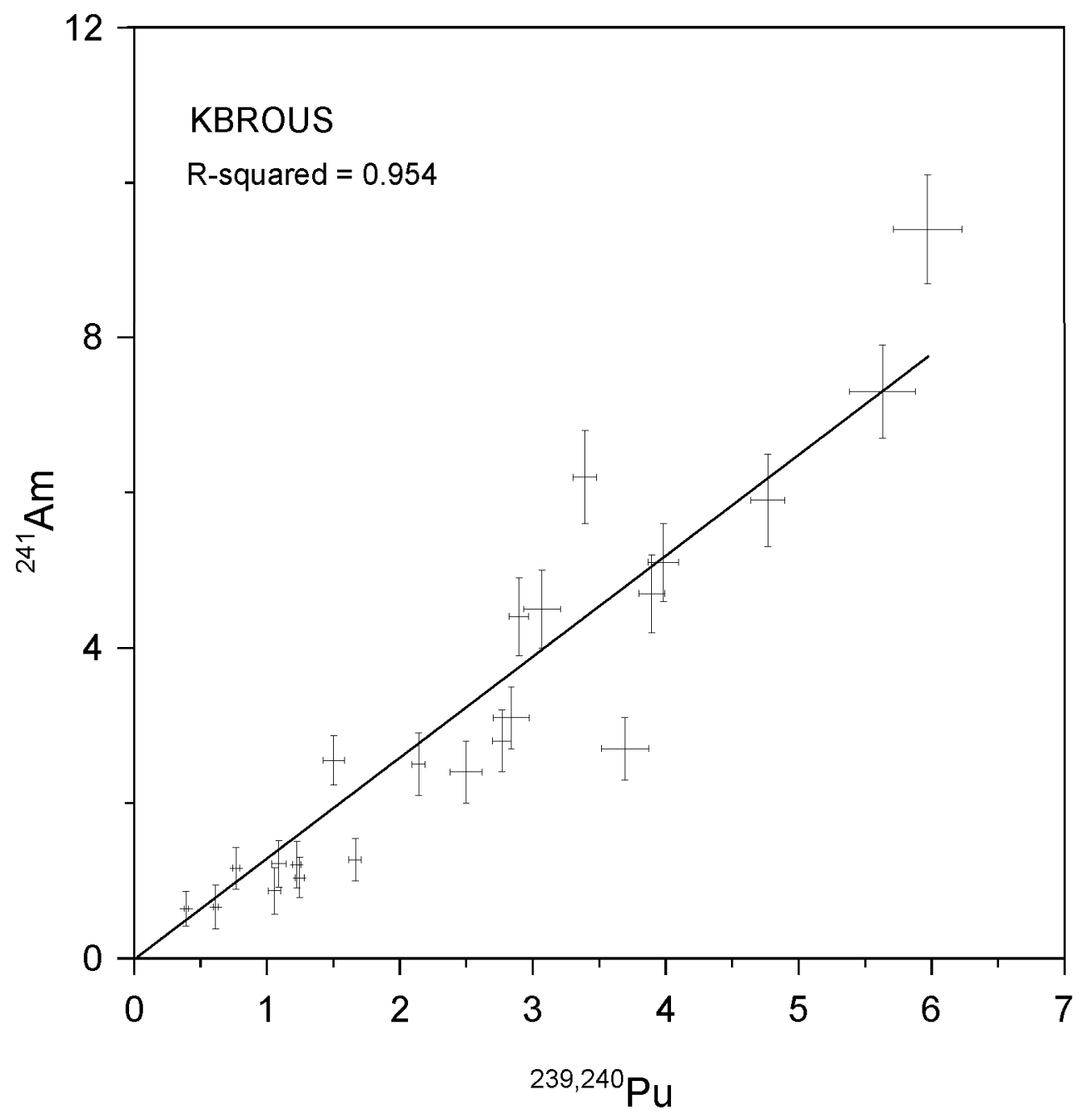




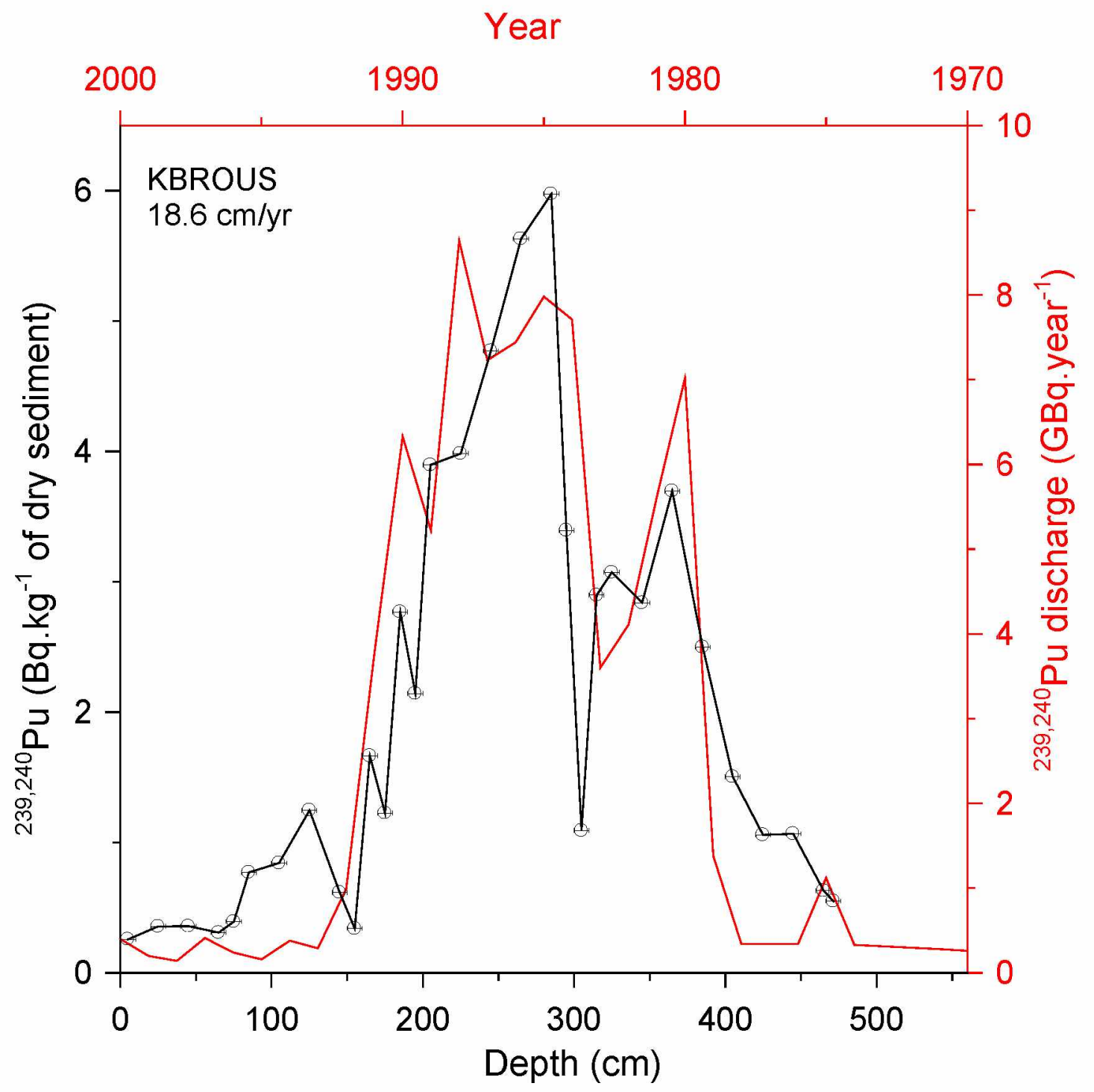



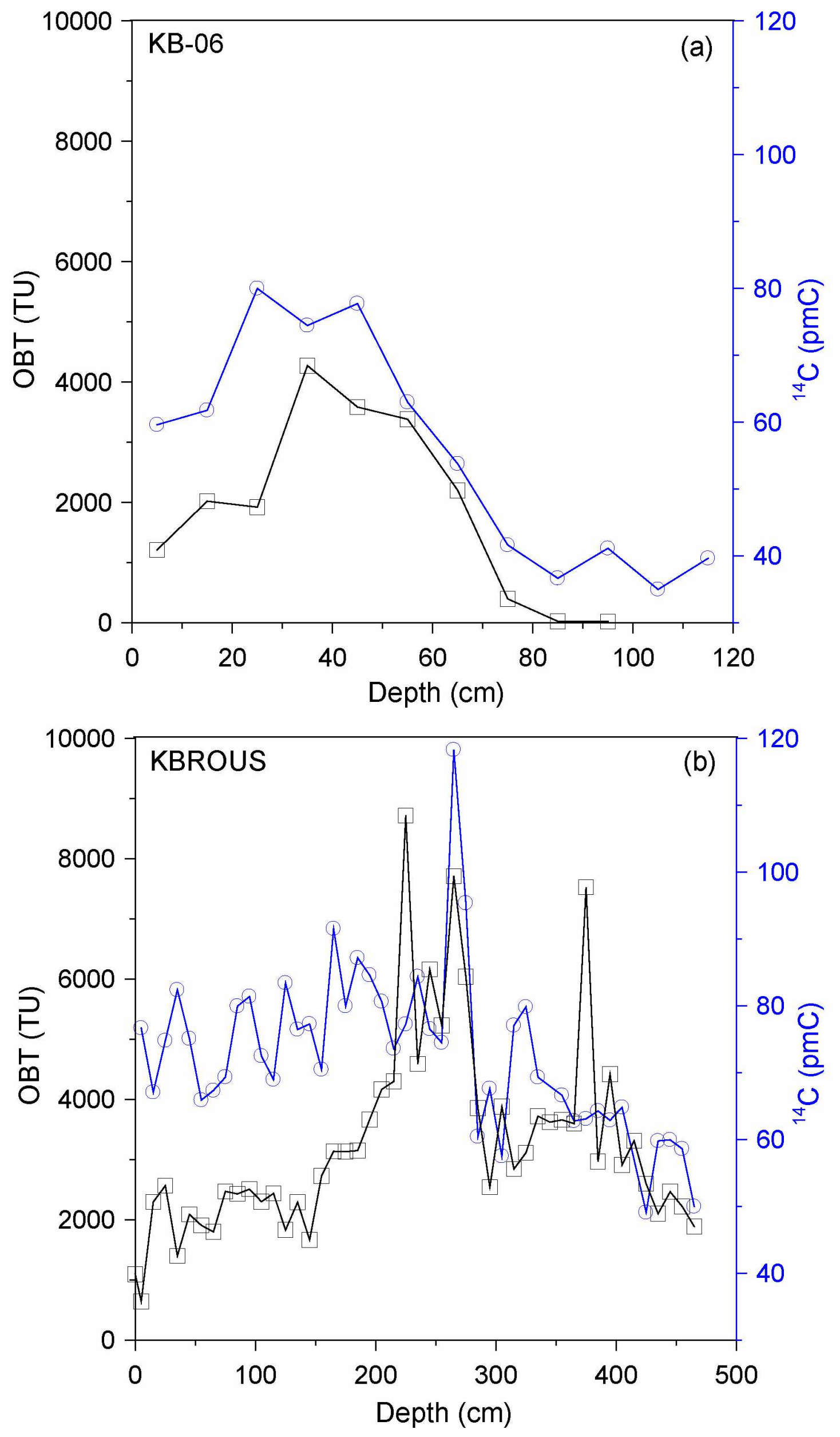


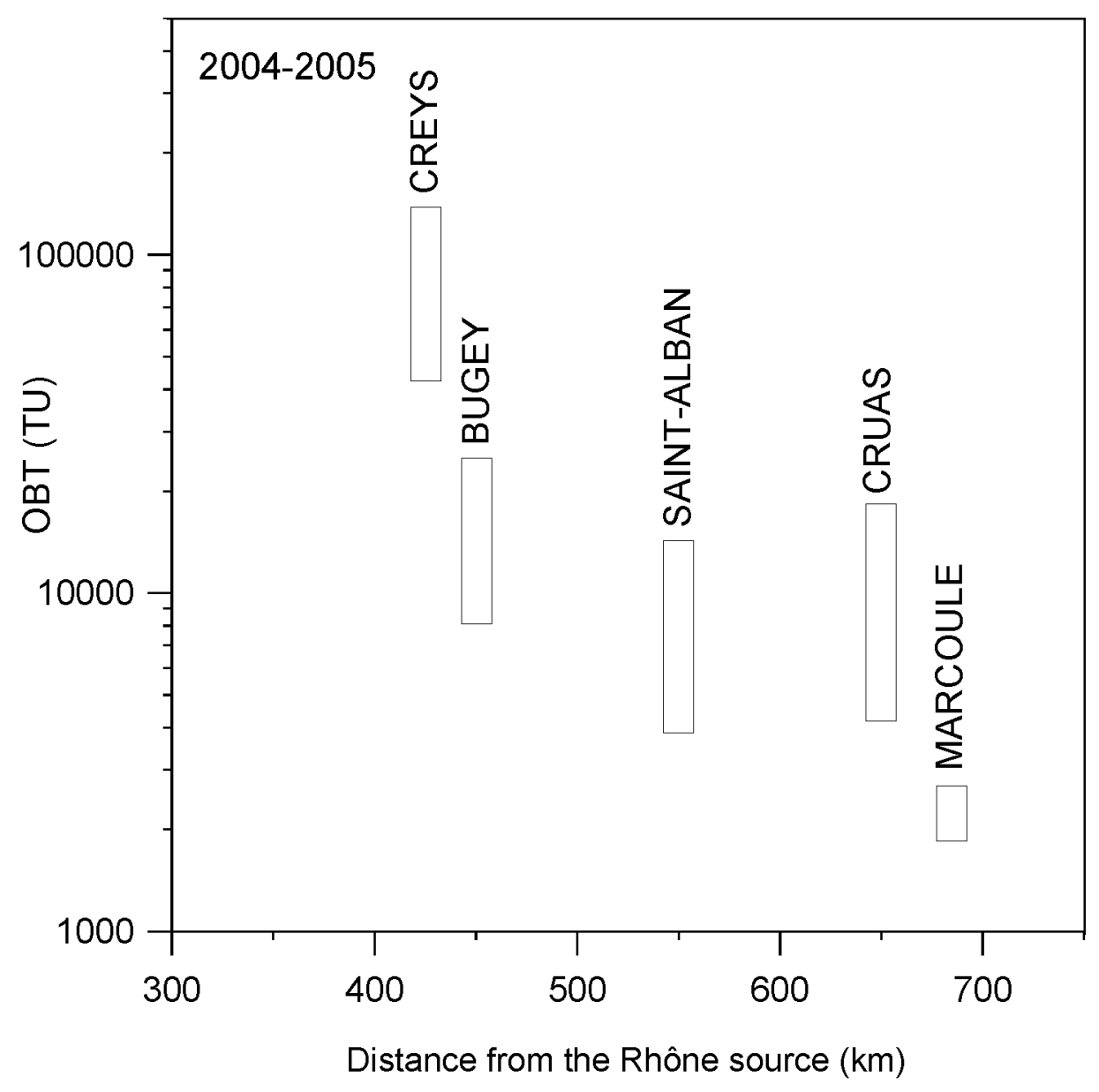




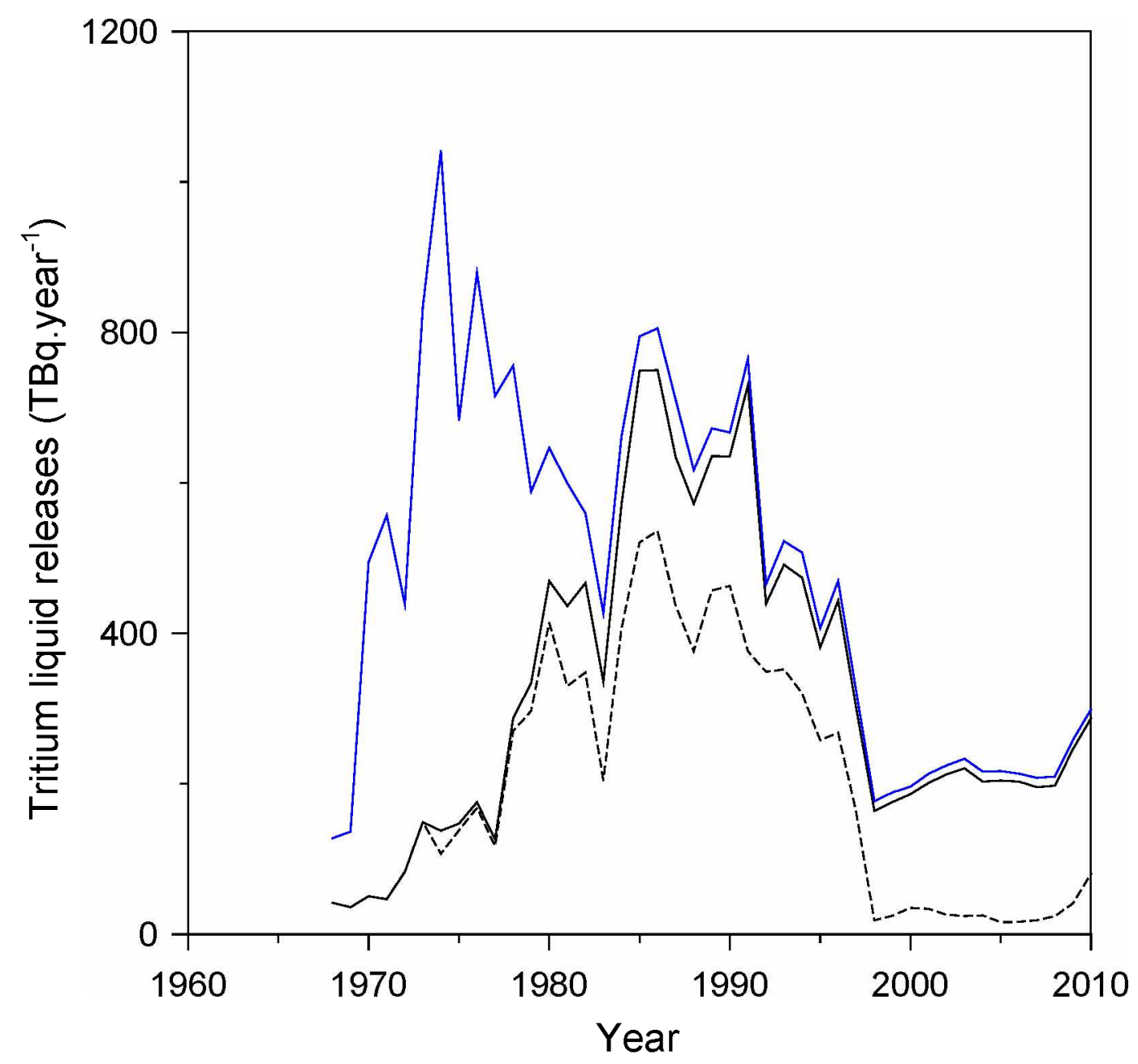




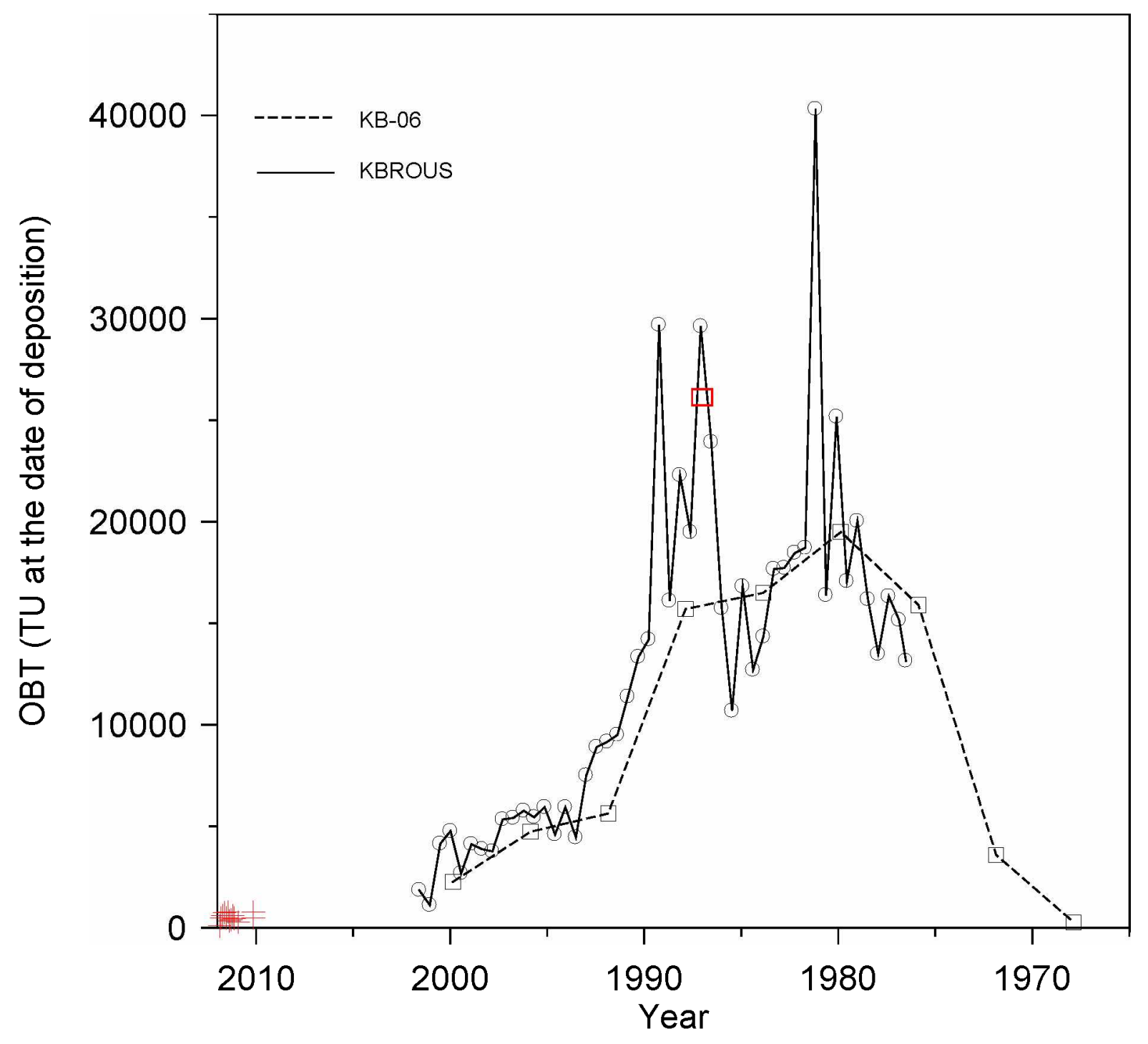




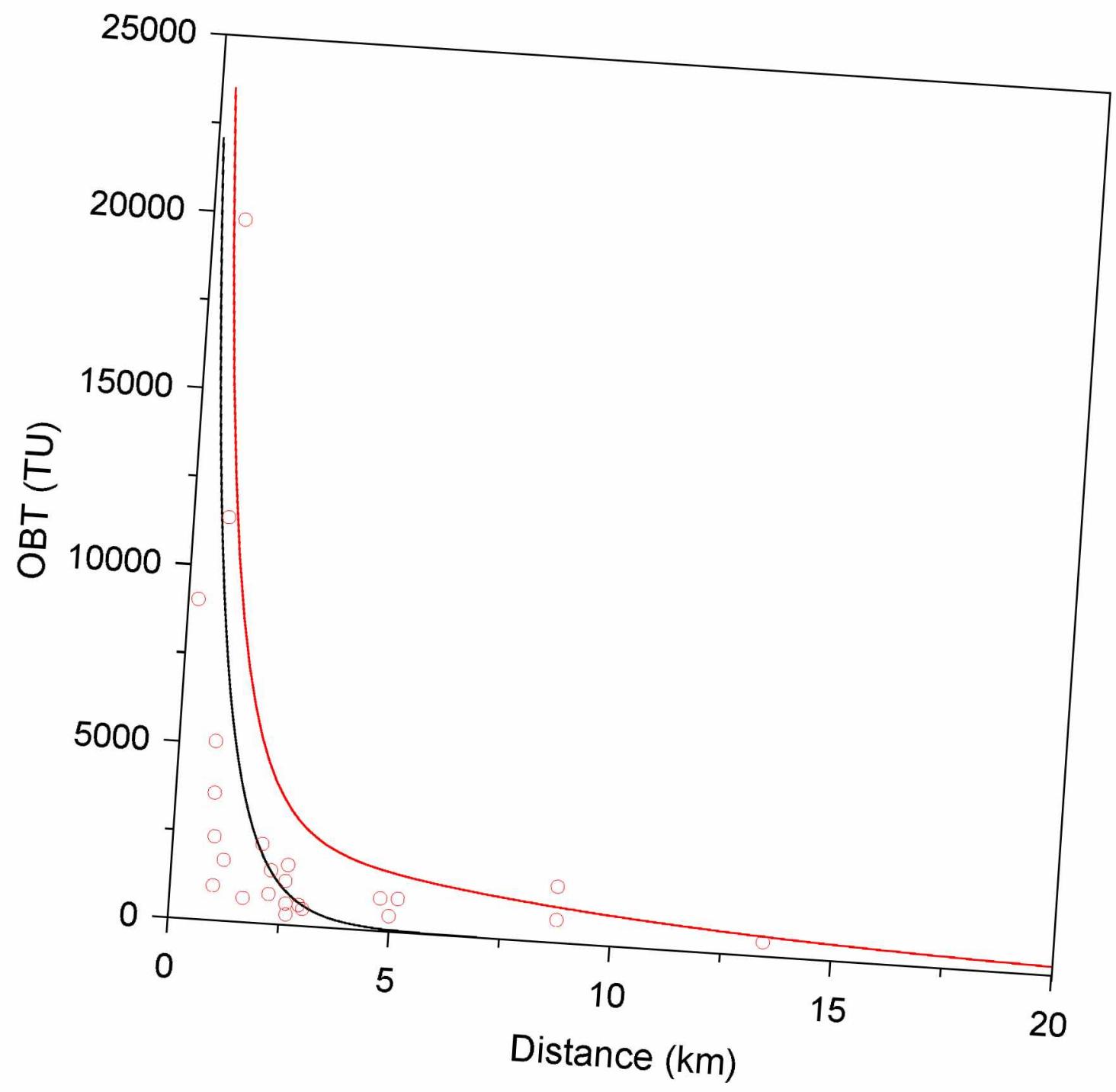

